\title{
Measurement of Attenuation Coefficients of Near Surface Material Using SASW Method
}

\author{
Suharsono \\ Geophysics UPN "Veteran" Yogyakarta \\ harsonomgl@yahoo.co.id
}

Received 19-02-2014, Revised 24-04-2014, Accepted 25-04-2014, Published 30-04-2014

\section{ABSTRACT}

The spectral analysis of surface waves (SASW) is an in situ non-destructive method. It has been developed and used for many years in the fields of geotechnical engineering and site characterization. It is typically used in evaluation of elastic moduli and layer thickness of soils, rocks and pavements.

In this study the SASW was used to measure an attenuation coefficient $(\alpha)$ of near surface material at 15 development sites with different material e.i. soils, granite and methamorphics rock.. The attenuation coefficient which is the exponential decay constant of the amplitude of surface wave propagation was approximated by Bornitz equation. The amplitude of vertical ground surface vibration generated by impact tests on the ground surface was measured at various radial distances.

A good empirical correlation between the measured attenuation coefficients and the corresponding shear modulus and SPT or RQD data were established. These results suggest that the attenuation coefficient could be used as an alternative parameter for characterization of near surface material. Based on this method, the subsurface material at sites the study can be classified into two groups. The first group represented a low stiffness material with attenuation values of greater than $0.00516 \mathrm{~s} / \mathrm{m}$ and the second group was a high stiffness material with attenuation values of less than $0.00150 \mathrm{~s} / \mathrm{m}$.

However, this method of evaluation was still in development stage and needs to be substantiated with more results of measurements.

Keywords : spectral analysis, surface wave, attenuation, shear moduli

\section{ABSTRAK}

Analisis Spektral Gelombang Permukaan adalah suatu metoda yang in situ tidak merusak. Metoda ini telah dikembangkan dan telah beberapa tahun digunakan dalam kegiatan geoteknik dan karakterisasi area pembangunan. Secara khusus digunakan dalam kajian modulus elastik dan ketebalan lapisan tanah, batuan dan konstruksi jalan raya.

Dalam penelitian ini analisis spektral gelombang permukaan diterapkan untuk menghitung koefisien antenuasi $(\alpha)$ dari lapisan dekat permukaan pada 15 area dengan material yang berbeda yakni pada tanah, batuan granit dan batuan metamorf.

Koefisien atenuasi yang tergambarkan sebagai konstanta peluruhan eksponsial dari amplitudo perambatan gelombang permukaan telah dirumuskan dalam persamaan Bornitz. Amplitudo getaran vertikal permukaan dihasilkan oleh hentakan/pukulan pada permukaan kemudian direkam pada berbagai jarak.

Korelasi empiris yang baik antara koefisien atenuasi terukur dan modulus geser yang bersesuaian dan SPT atau RQD telah diperoleh. Hasil ini menunjukkan bahwa koefisien atenuasi dapat digunakan sebagai parameter alternatif untuk karakterisasi material dekat permukaan.

Berdasarkan metoda ini, material dekat permukaan dapat diklasifikasikan dalam dua kelompok Kelompok pertama menggambarkan material dengan kekukuhan rendah dengan nilai atenuasi lebih besar dari 0,00516 detik/meter dan kelompok kedua adalah material dengan kekukuhan yang tinggi dengan nilai atenuasi lebih kecil dari 0,00150 detik/meter.

Kata kunci : analisis spectral, gelombang permukaan, atenuasi, modulus geser. 


\section{INTRODUCTION}

An understanding of the attenuation properties of the earth material has two major motivations. Firstly, seismic wave amplitudes are reduced as waves propagate through an elastic medium, and this reduction is generally frequency dependent. Second, attenuation characteristics reveal much information, such as lithology, physical state, discontinuity, stiffness and degree of saturation of rocks. Attenuation data complement other physical measurements for characterizing rock properties.

The most commonly usage of attenuation measurements are attenuation coefficient $(\alpha)$ which is the exponential decay constant of the amplitude of a plane wave travelling; the quality factor $\mathrm{Q}$ and its inverse $\mathrm{Q}^{-1}$, sometimes called the internal friction or dissipation factor; and the logarithmic decrement $(\delta)$. This paper will discuss the measurement of attenuation coefficient $(\alpha)$ of near surface material using SASW method.

The effects of soil stiffness on the value of attenuation coefficient have been investigated using Spectral Analysis of Surface Wave (SASW) method ${ }^{[1]}$. The amplitude of vertical ground surface vibration generated by impact tests on the ground surface was measured at various radial distances. The results were analyzed in the frequency domain and the characteristics of near surface materials were studied in terms of a frequency independent attenuation coefficient using the empirical Bornitz equation.

SASW has successfully evaluated the attenuation effects of surface wave propagation on rockmass material ${ }^{[2]}$. SASW is a non-destructive seismic method for site characterization (Figure 1). It is typically used in evaluation of elastic moduli and layer thickness of soils, rocks and pavements ${ }^{[3,4,]}$. In recent decades, extensive researches have been conducted to understand its applicability and limitations. SASW method is based on dispersive characteristics of Rayleigh waves, i.e., the dependency of velocity and frequency (or wavelength) of a wave. The dispersive behavior is exhibited by Rayleigh waves in nonuniform materials. The low frequency wave will extend into and be influenced by deeper material than a higher frequency wave.

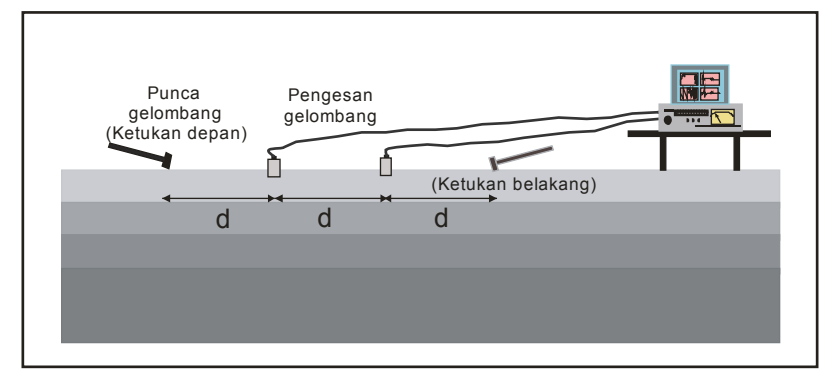

Figure 1.(color online) General configuration of the SASW method setup

The stiffness values derived from seismic tests, including SASW method, is usually denoted $\mathrm{G}_{\max }$. They represent very small strain stiffness, which is considered to be the maximum shear modulus exhibited by a material ${ }^{[5]}$.

The aim of this study is to evaluate the correlation between attenuation coefficients and the stiffness of near surface material. Based on best coherence of frequency range in each of geophone spacing, attenuation coefficient value and a dominant frequency would be obtained. In addition, the wavelength of surface wave could be determined using cross phase and wavelength relationship (equation 4.). 
Rayleigh waves are surface waves that travelling along a free surface, such as the earth-air interface and are the result of interfering $\mathrm{P}$ and $\mathrm{S}_{\mathrm{v}}$ waves. Particle motion in the fundamental mode of Rayleigh wave moving from source to receiver is elliptical in a counter clockwise (retrograde) direction. The motion is constrained to the vertical plane consistent with the direction of wave propagation ${ }^{[6]}$.

The conventional SASW measurements involve three basics steps: (1). Field testing, including generation of elastic surface waves in the test site and detection of them at several locations at the surface; (2) evaluation of the dispersion curve; and (3) inversion of the dispersion curve to obtain the shear modulus profile of the test site ${ }^{[7]}$.

In a homogeneous half space the Rayleigh waves are non-dispersive. The wavelength of Rayleigh wave $\left(\lambda_{R}\right)$ is related to the propagation velocity (also termed phase velocity) through the frequency of vibration following equation:

$$
V_{R}=f \cdot \lambda_{R}
$$

Approximately two-thirds of the impact energy of a hammer blow propagates in the form of surface waves ${ }^{[5]}$. The most explicit way to calculate the velocity that a wave travels is to use the travel time of the wave.

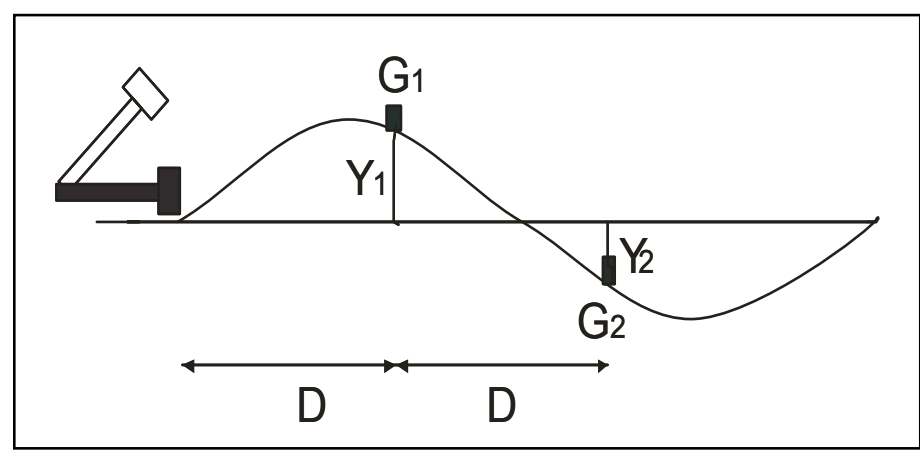

Figure 2. The phase different of Rayleigh wave at two locations

The travel time of a wave with a single frequency can be evaluated from the phase difference of the wave that is recorded at two locations ${ }^{[8]}$. Let a wave with the frequency of $f$, start to travel from energy source, pass through location $\mathrm{G}_{1}$ leading to location $\mathrm{G}_{2}$. The wave motion is described as $y_{1}$ at location $\mathrm{G}_{1}$ with time travel $t_{1}$ and $y_{2}$ at location $\mathrm{G}_{2}$ with time travel $t_{2}$ (Figure 2.).

The wave motions at locations $\mathrm{G}_{1}$ and $\mathrm{G}_{2}$ can be expressed as follows:

$$
\begin{aligned}
y_{1} & =\sin \left[2 \pi f t_{1}\right] \\
y_{2} & =\sin \left[2 \pi f\left(t_{1}-t_{2}\right)\right] \\
& =\sin \left[2 \pi f t_{1}-2 \pi f t_{2}\right] \\
& =\sin \left[2 \pi f t_{1}-n \varphi\right]
\end{aligned}
$$

where $n \varphi=2 \pi f t_{2}$, suggested the phase difference between the two locations for the wave travelling with frequency of $f$; while $n=1,2,3, \ldots, \sim$; indicates the cycle of waves on the cross phase function. 
The phase velocity $\left(V_{P H}\right)$ corresponding to the frequency $f$ between two locations $\left(\mathrm{G}_{1}\right.$ and $\left.\mathrm{G} 2\right)$ with distance $d$ can be expressed by:

$$
\begin{aligned}
V_{P H} & =\frac{l}{t_{2}} \\
& =\frac{? \pi d}{n \varphi}
\end{aligned}
$$

Therefore, the wavelength $(\lambda)$ corresponding to the frequency $(f)$ can be expressed by:

$$
\begin{aligned}
V_{P H} & =f \frac{2 \pi d}{n \varphi} \\
& =f \lambda \\
\lambda & =\frac{2 \pi d}{n \varphi}
\end{aligned}
$$

The loss of energy vibration or amplitude of Rayleigh waves due to geometrical and geomaterial damping is given by Bornitz equation :

$$
\mathrm{A}_{2}=A_{1} \sqrt{\frac{r_{1}}{r_{2}}} \mathrm{e}^{-\alpha\left(r_{2}-\right) \mathrm{f}}
$$

where $r_{1}$ and $r_{2}$ are the distance from source to geophones $G_{1}$ and $G_{2}$ respectively. $A_{1}$ and $A_{2}$ are the amplitude of Rayleigh wave at $\mathrm{G}_{1}$ and $\mathrm{G}_{2}$; whereas $\alpha$ is the attenuation coefficient. The calculation of the stiffness-depth profile is based on the elastic theory where the velocity of the shear wave propagation $\left(\mathrm{V}_{\mathrm{s}}\right)$ is related to $\mathrm{V}_{\mathrm{R}}$ by:

$$
V S=\eta V_{R}
$$

$\eta$ is a rather complicated function of Poisson's ratio $(v)$. The complete equation of $\eta$ is called cubic equation in $\eta^{2[9]}$ :

$$
\eta^{6}-8 \eta^{4}-\left(16 v^{2}-24\right) \eta^{2}-16\left(1-v^{2}\right)=0
$$

The shear modulus $(G)$ is then relates to $V_{R}$ by:

$$
G=\rho V_{S}^{2}
$$

where $\rho$ is the bulk density of the near surface material.

\section{METHOD}

In this field test, the Rayleigh waves are detected using two geophones planted on the ground surface at known distances along a line, which is collinear with the wave source. The generation of Rayleigh wave is achieved by using transient sources (various hammers and a dropped weight). The geophone sensors with a natural frequency of $1 \mathrm{~Hz}$ seismometer (Mark Product model L-4) are arranged as shown as in Figure 3. The arrangement of these geophones spacing is often called the common receivers midpoint geometry and it is 
commonly used in the SASW method ${ }^{[10,8,5,3,]}$. The depth $(z)$ of corresponding attenuation values may be estimated from the wavelength analysis based on simple equation of $\lambda / z=2$ $[11,12,13$,$] . The geophone space used in this study are 1, 2, 4, 8, and 16$ meters.

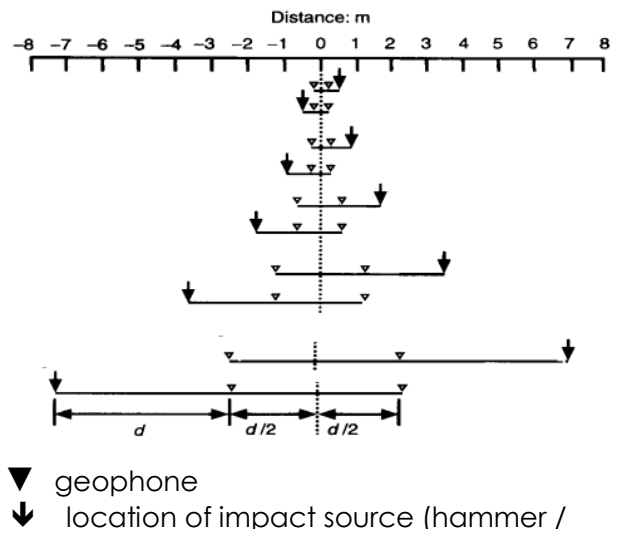

Figure 3. The geophone spacing of the measurements

Due to the limitations of recording equipment and the attenuation properties of the near surface materials, the distance $(\mathrm{d})$ of source to receiver $1\left(\mathrm{G}_{1}\right)$ or the distance from receiver 1 $\left(G_{1}\right)$ to receiver2 $\left(G_{2}\right)$, should consider the following empirical rules, $\lambda / 4 \leq L$ and $\lambda / 16 \leq \mathrm{d}<\lambda$, where $\mathrm{L}=(3 / 2) \mathrm{d}$ and $\lambda$ is the wavelength of the Rayleigh wave under consideration $^{[14,5]}$.

As a recording system the OROS25 spectrum analyzer that captures signal from the ground motion sensors in the time domain was used in this survey. The time domain data is transformed into the frequency domain.

The spectral ratio $\left(A_{2} / A_{1}\right)$ i.e. ratio of the amplitudes of Rayleigh wave that are recorded at $G_{2}$ and $\mathrm{G}_{1}$ could be obtained from the recording data. This spectral ratio for the range frequency is assumed approximately as an exponential curve. The plot will act as a fingerprint of the near-surface material and is called experimental curve. The spectral ratio versus frequency experimental curve has been best fitted to a theoretical curve that is described by Bornitz equation (eq. 5). For each geophones spacing, the value of attenuation $(\alpha)$ could be obtained by trial and error method so that the experimental and theoretical curves are fit together.

Three sites i.e. Kamsis H UKM, Bangi, Bandar Sri Putra and Bandar Sri Damansara are selected for the SASW measurements. The N-SPT data from the available borehole at each measurement site were used for comparison purposes.

\section{RESULT AND DISCUSSION}

Interpretation and analysis of the SASW data comprises of four main steps: (1) determining the range of frequencies based on the best coherence value; (2) determining the dominant frequency and corresponding wavelength; (3) calculating the attenuation coefficient for each geophones spacing and; (4) evaluating the attenuation values with shear modulus and N SPT from borehole data.

Range of frequencies could be determined directly during the field-testing based on the coherence function. It is necessary to calculate the wavelength corresponding to all those range of frequencies and determine the dominant frequency based on the spectrum histories. The value of dominant frequency and its associated wavelength can then be calculated. 
The attenuation values are compared with shear modulus results from the conventional inversion analysis and N-SPT (Standard Penetration Test) values. The inversion analysis for Sri Damansara and Kamsis H UKM sites are carried out using WinSASW1.0; and for Bandar Sri Putra site, the analysis is conducted using WinSASW2.0.

The results of the study reveal that the measured attenuation coefficients coincide well with the shear modulus and N SPT values (Table 1). For UKM site, the near surface material can be generally characterized in two groups i.e. the group of low stiffness material with N SPT of 12 which corresponds to an attenuation coefficient of $0.00308 \mathrm{~s} / \mathrm{m}$ and shear modulus of $0.06 \mathrm{MPa}$. The second group indicates high stiffness material with N SPT of greater than 50, which can be, correlated with attenuation coefficient and Gmax values of less than 0.00213 $\mathrm{s} / \mathrm{m}$ and 1.01 MPa respectively.

The results of measurement at Bandar Sri Putra site indicate the presence of both low and high stiffness materials. The low stiffness material is characterized by N SPT values with the range from 14 to 20; attenuation coefficient of $0.00516-0.00369 \mathrm{~s} / \mathrm{m}$ and shear modulus between 0.27-0.61 MPa. Whereas the high stiffness material shows N SPT value greater than 50 which correlates well with the attenuation coefficient and shear modulus values ranging from 0.00273 to $0.00150 \mathrm{~s} / \mathrm{m}$ and 1.22 to $2.47 \mathrm{MPa}$, respectively. Similar trend of results is obtained for Sri Damansara site (Figure 4).

Table 1 Examples of measurement and the results of analysis data

\begin{tabular}{|c|c|c|c|c|c|c|c|}
\hline No. & $\mathrm{D}(\mathrm{m})$ & $\mathrm{f}(\mathrm{Hz})$ & $\lambda(\mathrm{m})$ & Depth (m) & G(MPa) & $\mathrm{N}$ & Att. (s/m) \\
\hline \multicolumn{8}{|c|}{ UKM } \\
\hline 1 & 1 & 180 & 1.98 & 0.99 & 0.06 & 12 & 0.00308 \\
\hline 2 & 2 & 150 & 5.43 & 2.6 & 1.01 & $>50$ & 0.00210 \\
\hline 3 & 4 & 153 & 5.2 & 2.72 & 1.01 & $>50$ & 0.00213 \\
\hline 4 & 8 & 46 & 20.9 & 10.45 & 1.98 & $>50$ & 0.00189 \\
\hline 5 & 16 & 36.8 & 33.6 & 16.80 & 2.89 & $>50$ & 0.00165 \\
\hline \multicolumn{8}{|c|}{\begin{tabular}{|l|l|} 
B. Sri Putra &
\end{tabular}} \\
\hline 6 & 1 & 169 & 1.52 & 0.76 & 0.27 & 16 & 0.00516 \\
\hline 7 & 2 & 91.8 & 4.75 & 2.38 & 0.61 & 20 & 0.00369 \\
\hline 8 & 4 & 32 & 22.9 & 11.45 & 1.22 & $>50$ & 0.00273 \\
\hline 9 & 8 & 34.4 & 26.8 & 13.40 & 2.86 & 50 & 0.00152 \\
\hline 10 & 16 & 31.2 & 31.4 & 15.70 & 4.27 & $>50$ & 0.00150 \\
\hline \multicolumn{8}{|c|}{ Damansara } \\
\hline 11 & 1 & 65 & 3.4 & 0.71 & 0.04 & 6 & 0.00666 \\
\hline 12 & 2 & 100 & 2.24 & 1.28 & 0.05 & 10 & 0.00689 \\
\hline 13 & 4 & 117 & 4.61 & 3.00 & 0.90 & 43 & 0.00314 \\
\hline 14 & 8 & 36 & 18.8 & 12.30 & 1.57 & $>50$ & 0.00243 \\
\hline 15 & 16 & 40 & 30.4 & 14.97 & 2.86 & $>50$ & 0.00157 \\
\hline
\end{tabular}

The results of this study show that there is a good empirical correlation between the measured attenuation coefficients and the corresponding values of shear modulus and SPT data. The results indicate that the attenuation coefficient could be used as an alternative parameter to characterize the near surface material stiffness. However, more data are needed to substantiate this finding. 


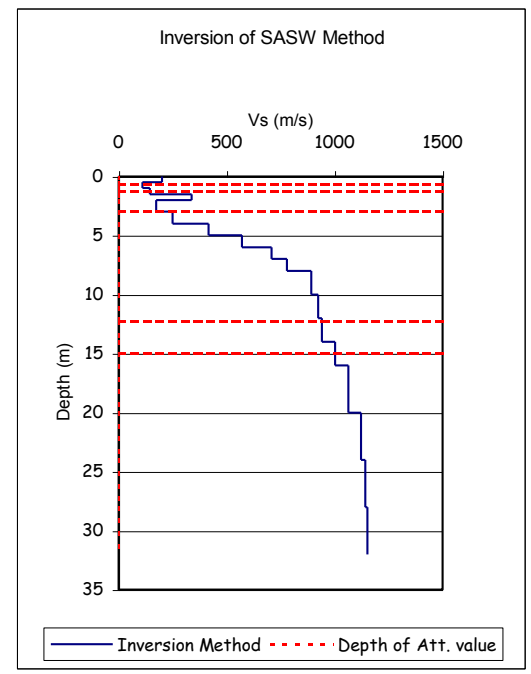

Figure 4 (color online) Comparison: Alternative and Inversion analysis with N SPT value, Sri Damansara Site

\section{CONCLUSION}

The results of this study indicate that the measured attenuation values of near surface material can be correlated well with the corresponding shear modulus (Gmax) and N SPT values. The attenuation coefficients could be used as an alternative parameter to determine the stiffnessdepth profile of subsurface material.

The spectral analysis of surface wave method has a possibility to overcome the difficulties of attenuation measurements and promising a practical method of future field measurement for site characterization. In addition, the common receivers midpoint geometry of geophone spacings used in this study is able to give both attenuation coefficients and depths information simultaneously.

\section{REFERENCES}

1 Athanasopoulus, G.A., Pelekis, P.C. and Anagnostopoulus, G.A. 2000. Effect of Soil Stiffness in the Attenuation of Rayleigh Wave Motions from Field Measurements. Soil Dynamics and Earthquake Engineering, Vol. 19, pp. 277-288.

2 Suharsono and Abdulrahim. 2003. The Attenuation Effects of Surface-Wave Propagations on Rockmass Using SASW Method. Geological Society of Malaysia Bulletin, Vol. 46, pp. 475-478.

3 Gucunski, N, Ganji, V. and Maher, M.H. 2000. Effects of Soil Non-homogeneity on SASW testing. Geotechnical Special Publication No.58, ASCE, pp. 1083-1097

4 Ganji, V., Gucunski, N. and Nazarian, S. 1998. Automated Inversion Procedure for Spectral Analysis of Surface wave. Journal of Geotechnical and Environmental Engineering, pp. 753-770.

5 Matthews, M.C. 1996. The Use of Surface Waves in the Determination of Ground Stiffness Profile. Proc. Instn. Civ. Engrs. Geotechnical Engineering.

6 Jianghai, X., Miller, R.D., Choon, B.P. and Gang, T. 2002. Determining Q of NearSurface Materials from Rayleigh Wave. Journal of Applied Geophysics, Vol. 51, pp. 121-129. 
7 Ganji, V., Gucunski, N. and Nazarian, S. 1998. Automated Inversion Procedure for Spectral Analysis of Surface wave. Journal of Geotechnical and Environmental Engineering, pp. 753-770.

8 Joh, S.H. 1996. Advances in Interpretation and Analysis Techniques for SASW Measurements. Dissertation (Not published), The University of Texas at Austin.

9 Das, B.M. 1983, Fundamentals of Soil Dynamic. Elsevier Science Publishing Co., Inc.

10 Kim, D.S., Shin, M.K. and Park, H.C. 2000. Evaluation of Density in Layer Compaction Using SASW Method. Soil Dynamic and Earthquake Engineering, Vol. 21, pp. 39-46.

11 Ballard, R.F. and Mc Lean, F.G. 1975. Seismic Field Methods for In-Situ Moduli. Proc. Conf. On In Situ Measurements Of Soil Properties: Spec. Conf. Geotech. Eng. Div. $A S C E$, North Carolina, Vol. 1, pp. 121-150.

12 Jones, R.B. 1958. In-Situ Measurements of the Dynamic Properties of Soil by Vibration Methods. Geotechnique, Vol. 8, No. 1, pp. 1-21.

13 Gazetas, G. 1982. Vibrational Characteristics of Soil Deposits with Variable Velocity. Journal of Numerical Analytical Methods on Geomechanical,Vol. 6, pp. 1-20.

14 Tokimatsu, K. H. 1996. Effects of Multiple Modes on Rayleigh Wave Dispersion Characteristics. Proc. ASCE J. Geotech. Eng, Vol. 118, No.10, pp. 1529-1543. 